\title{
Comparison of innate immune responses and somatotropic axis components of Holstein and Montbéliarde-sired crossbred dairy cows during the transition period
}

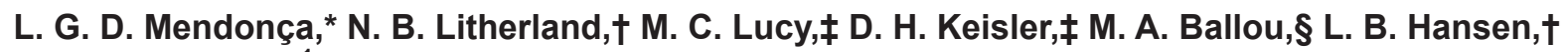 \\ and R. C. Chebel*1 \\ *Department of Veterinary Population Medicine, and \\ †Department of Animal Sciences, University of Minnesota, St. Paul 55108 \\ ‡Department of Animal Sciences, University of Missouri, Columbia 65211 \\ $\S$ Animal and Food Sciences, Texas Tech University, Lubbock 79409
}

\begin{abstract}
Objectives were to compare parameters related to innate immune responses and somatotropic axis of Holstein (HO) and Montbéliarde (MO)-sired crossbred cows during the transition from late gestation to early lactation. Cows (40 $\mathrm{HO}$ and $47 \mathrm{MO}$-sired crossbred) were enrolled in the study $45 \mathrm{~d}$ before expected calving date (study d $0=$ calving). Polymorphonuclear leukocytes (PMNL) isolated from blood samples collected weekly from study d -7 to 21 and on study d 42 were used for determination of percentage of PMNL positive for phagocytosis $(\mathrm{PA}+)$ and oxidative burst $(\mathrm{OB}+)$, intensity of PA and $\mathrm{OB}$, percentage of PMNL expressing CD18 (CD18+) and L-selectin (LS+), and intensity of CD18 and LS expression. Blood was sampled weekly from study d -7 to 14 and on study d 28, 42, and 56 for determination of insulin, growth hormone (GH), leptin, and insulin-like growth factor (IGF)-1 concentrations. Blood sampled weekly from study d -14 to 21 and on study d 42 was used to determine cortisol concentration. Liver biopsies were performed on study $\mathrm{d}-14,7,14$, and 28 for determination of mRNA expression for insulin receptor B (IRB), total GH receptor (GHRtot), GHR variant 1A (GHR1A), and IGF-1. Data were analyzed by ANOVA for repeated measures or by ANOVA using the GLM procedure of SAS (SAS Institute Inc., Cary, NC). Intensity of CD18 expression was greater in PMNL from crossbred cows compared with PMNL from HO cows $[1,482.1 \pm 82.3$ vs. $1,286.6$ \pm 69.8 geometric mean fluorescence intensity (GMFI)]. Furthermore, among $\mathrm{HO}$ cows, the percentage of PA+ PMNL on study $\mathrm{d}-7(64.4 \pm 5.2 \%)$ tended to be greater than on study d $0(57.1 \pm 5.1 \%)$, but no differences in percentage of PA+ PMNL between study d -7 and 0 were observed in crossbred cows. Similarly,
\end{abstract}

Received June 4, 2012.

Accepted February 4, 2013.

${ }^{1}$ Corresponding author: chebe002@umn.edu intensity of PA in PA+ PMNL from $\mathrm{HO}$ cows decreased from study $\mathrm{d}-7$ to $0(4,750.6 \pm 1,217.0$ vs. $1,964.7 \pm$ 1,227.9 GMFI), but no changes in intensity of PA in PA+ PMNL from crossbred cows were observed. On study d 0, intensity of PA tended to be reduced in PA+ PMNL from HO cows compared with PA+ PMNL from crossbred cows $(1,964.7 \pm 1,227.9$ vs. 4,688.1 $\pm 1,271.8$ GMFI). Concentrations of GH (7.4 \pm 0.4 vs. $5.1 \pm 0.4$ $\mathrm{ng} / \mathrm{mL})$ and cortisol $(9.5 \pm 0.8$ vs. $7.1 \pm 0.8 \mathrm{ng} / \mathrm{mL})$ were greater for $\mathrm{HO}$ than for crossbred cows. Crossbred cows had improved innate immune responses compared with $\mathrm{HO}$ cows, as determined by a lack of decrease in intensity of PA on the day of calving, which may result in improved health. Furthermore, HO cows appeared to be less sensitive to the negative feedback of IGF-1 on $\mathrm{GH}$ secretion because cows from both breeds had similar IGF-1 concentrations but MO-sired crossbred cows had greater GH concentrations.

Key words: crossbreeding, innate immunity, somatotropic axis, dairy cow

\section{INTRODUCTION}

Highly inbred populations have increased homozygosity and inbreeding depression, characterized by reduced performance. Inbreeding is the probability of 2 alleles at any locus being identical by descent (Falconer and Mackay, 1996). According to the United States Department of Agriculture, average inbreeding in the Holstein breed has increased from $0.41 \%$ in 1970 to $5.85 \%$ in 2012 (US Department of Agriculture, 2012). O'Brien and Evermann (1988) suggested that immune responses may be impaired in populations with elevated inbreeding as a result of decreased genetic variability. Inbred wild bird populations show compromised cell mediated (Reid et al., 2003) and innate (Townsend et al., 2010) immune responses. Cartwright et al. (2011) demonstrated that purebred Holstein (HO) calves (2 to 6 mo of age) had reduced antibody-mediated immunity 
compared with Norwegian Red-HO crossbred calves. Furthermore, HO cows are more likely to develop postpartum uterine diseases compared with Montbéliarde (MO)-sired crossbred cows (Mendonça et al., 2010a), and MO-sired crossbred cows have reduced likelihood of death and removal from the herd within the first 35 DIM compared with purebred HO cows (Heins et al., 2012). The association between heterosis or breed complementarity and immune responses of periparturient dairy cows, however, has been investigated only rarely.

Innate immunity plays a critical role in the health of dairy cows during the transition period, 3 wk pre- to 3 wk postpartum (Cai et al., 1994). During the transition period, the functionality and activity of PMNL are of particular importance because they are involved with expulsion of the placenta following parturition (Kimura et al., 2002) and because PMNL are the first line of defense of the uterus against invading pathogens (Singh et al., 2008). The functionality and activity of PMNL of dairy cows is influenced by negative energy balance during the periparturient period (Hammon et al., 2006), and high NEFA concentrations are associated with impaired innate (Hammon et al., 2006) and adaptive (Lacetera et al., 2005) immune function. Even though measuring PMNL phagocytic and killing ability is crucial to determine PMNL activity, transport of PMNL from capillary veins to the site of infection determines the ability of the host organism to produce the migration of a large enough number of PMNL to clear infection. Adhesion molecules (i.e., L-selectin and CD18) expressed on the surface of PMNL are involved in the trafficking of neutrophils from the endothelium to the site of inflammation (Burton et al., 1995). During parturition, elevated concentrations of cortisol are believed to induce immunosuppression by reducing expression of L-selectin and CD18 in the surface of neutrophils (Burton et al., 1995).

The continued increase in milk yield of periparturient dairy cows even during negative energy balance results from the uncoupling of the somatotropic axis, characterized by decreased growth hormone receptor (GHR) expression in the liver and consequently reduced IGF-1 synthesis by the liver (Lucy et al., 2009). This results in reduced negative feedback of IGF-1 on growth hormone (GH) secretion, and, consequently, increased GH and reduced IGF-1 concentrations (Lucy et al., 2009). Increasing concentrations of GH during periods of severe negative energy balance exacerbate lipolysis and production of NEFA destined to de novo fat synthesis in the mammary gland (Etherton and Bauman, 1998). The degree of uncoupling of the somatotropic axis during the periparturient period seems to be dependent on genetic strains and appears to be exacerbated in $\mathrm{HO}$ cows with North American genetics (Lucy et al., 2009; Grala et al., 2011).

The hypotheses of the current study were that (1) MO-sired crossbred cows would have improved innate immune responses during the transition period compared with HO cows; and (2) the degree of uncoupling of the somatotropic axis of MO-sired crossbred cows would be reduced compared with that of $\mathrm{HO}$ cows. The objectives of the current study were to compare the innate immune function and the degree of uncoupling of the somatotropic axis of purebred $\mathrm{HO}$ and MO-sired crossbred cows during the transition period. The MOsired crossbred cows were chosen because these have been reported to have reduced likelihood of postpartum death compared with HO cows (Heins et al., 2012) and because MO-sired crossbred cows have been reported to have similar milk yield and BW to $\mathrm{HO}$ cows (Walsh et al., 2008).

\section{MATERIALS AND METHODS}

\section{Cows, Breeds, and Enrollment Period}

The study was conducted at the University of Minnesota's St. Paul dairy. Cows used in the current study were a subset of cows $(\mathrm{n}=87)$ enrolled in a larger study (Mendonça et al., 2010a,b). In the current study, 40 HO (31 lactation $\geq 1$ and 9 nulliparous) and $47 \mathrm{MO}$-sired crossbred (42 lactation $\geq 1$ and 5 nulliparous) cows were used. Hereafter, cows that had their first calving during the study will be referred to as primiparous and cows that had their second or later calving during the study will be referred to as multiparous.

Cows were enrolled in the study $45 \mathrm{~d}$ before expected calving date and were followed until 90 DIM (study d $0=$ calving date). The enrollment period was from October 2009 to January 2010 (first season of parturition) and during the month of September 2010 (second season of parturition). Cows were fed a TMR once daily and water was available ad libitum. The TMR offered during the dry period consisted of wheat straw, corn silage, alfalfa hay, ground dry corn, soybean meal (first season of parturition), and a protein mix. The lactating cow TMR consisted of corn silage, alfalfa hay, ground dry corn, soybean meal (first season of parturition), whole cottonseed (second season of parturition), and a protein mix. Description of BW, BCS, DMI, and health and metabolic parameters are reported in Mendonça et al. (2010b, 2012).

\section{Blood Sample Collection}

Blood samples were collected via coccygeal vein or artery immediately before feeding while cows were rest- 
ing. Needles used were 22 gauge and $2.54 \mathrm{~cm}$ long to minimize stress during sample collection. Blood samples collected weekly from study d -7 to 21 and on study d 42 into heparinized evacuated tubes (Becton Dickinson Vacutainer Systems, Franklin Lakes, NJ) were used for evaluation of ex vivo innate immune function. Blood sampled weekly from study d -7 to 14 and on study d 28, 42, and 56 into evacuated tubes without anticoagulant and into evacuated tubes with EDTA (Becton Dickinson Vacutainer Systems) was used for determination of serum concentrations of insulin, GH, and leptin, and plasma concentration of IGF-1. Blood samples collected weekly from study $\mathrm{d}-14$ to 21 and on study d 42 into tubes without anticoagulant were used for determination of cortisol concentration. Tubes were placed on ice until centrifugation for serum or plasma separation $\left(1,200 \times g\right.$ for $15 \mathrm{~min}$ at $\left.4^{\circ} \mathrm{C}\right)$, and harvested serum or plasma was stored at $-32^{\circ} \mathrm{C}$ until analysis.

\section{Innate Immune Response Assays}

In a subgroup of cows $[\mathrm{HO}=29$ (20 multiparous and 9 primiparous) and crossbred $=33$ (29 multiparous and 4 primiparous)], ex vivo innate immune parameters were evaluated as described by Hulbert et al. (2011). Briefly, expression of L-selectin (LS) and CD18 by peripheral PMNL was determined by indirect immunofluorescence staining. Briefly, the assay consisted of incubating $200 \mu \mathrm{L}$ of whole blood at $4^{\circ} \mathrm{C}$ for $30 \mathrm{~min}$ with $5 \mu \mathrm{g} / \mathrm{mL}$ of anti-bovine CD62L (DU1-29, VMRD Inc., Pullman, WA) monoclonal antibody produced in mouse or $2.5 \mu \mathrm{g} / \mathrm{mL}$ of anti-bovine CD18 (BAT75A, VMRD Inc.) monoclonal antibody produced in mouse. Before incubation of the cells with an anti-mouse IgGfluorescein isothiocyanate (FITC) secondary polyclonal antibody (AbD Serotec, Raleigh, NC) diluted 1:400 in PBS solution (Sigma-Aldrich, St. Louis, MO), erythrocytes were lysed with hyperconcentrated PBS solution. After washing the cells with PBS solution, samples were analyzed by flow cytometry. Blood from nondiseased cows was used as positive and negative controls in all assays. Negative controls consisted of incubating $200 \mu \mathrm{L}$ of PBS solution instead of the monoclonal antibody. Phagocytic (PA) and oxidative burst (OB) activity of peripheral PMNL were determined upon challenge with enteropathogenic bacteria (Escherichia coli 0118:H8), as described by Hulbert et al. (2011). Briefly, the assay to determine PA and OB consisted of incubating $200 \mu \mathrm{L}$ of whole blood with $40 \mu \mathrm{L}$ of $100 \mu M$ dihydrorhodamine 123 (Molecular Probes/Invitrogen, Eugene, OR), an oxidative-sensitive indicator, and 40 $\mu \mathrm{L}$ of fluorescently labeled bacteria $\left(10^{9} \mathrm{cfu} / \mathrm{mL}\right)$ at $38.5^{\circ} \mathrm{C}$ for $15 \mathrm{~min}$, with surface bacteria fluorescence removed using Trypan Blue solution (0.4\%; SigmaAldrich). After washing with milliQ water to remove excess dye, erythrocytes were lysed by the addition of hyper-concentrated PBS solution (Sigma-Aldrich). Finally, the cells were resuspended in PBS solution for immediate flow cytometry analyses. Blood from nondiseased cows was used as positive and negative controls. Unlabeled bacteria were used as negative controls for the phagocytosis assay, and samples that received no dihydrorhodamine 123 served as negative controls for the oxidative burst assay. All flow cytometry data were collected on a BD FACSCANTO II (BD Biosciences, Franklin Lakes, NJ) and analyzed using FlowJo 7.6.4 software (Tree Star Inc., San Carlos, CA). The PMNL population was identified on basis of forward and side scattered properties. After strictly gating the PMNL population, data from 3 parameters were collected for analysis: forward scatter, side scatter, and log fluorescence. Data are reported as PMNL intensity of phagocytosis, oxidative burst, and expression of CD18 and L-selectin molecules expressed in geometric mean fluorescence intensity (GMFI). Phagocytic and adhesion molecule intensity were indirect indications of the number of phagocytized bacteria and adhered molecules by PMNL, respectively. Oxidative burst intensity was an indirect indication of the amount of reactive oxygen species produced via oxidation of dihydrorhodamine 123. Furthermore, percentages of PMNL positive for phagocytosis $(\mathbf{P A}+)$, oxidative burst activity $(\mathbf{O B}+)$, and expression of CD18 (CD18+) and L-selectin $(\mathbf{L S}+)$ molecules were calculated.

\section{Hormone Assays}

Serum cortisol concentrations were determined by a solid-phase RIA kit (Coat-a-Count, Siemens Medical Solutions Diagnostics, Los Angeles, CA). The intraand interassay coefficients of variation were 5.8 and $11.7 \%$, respectively.

Insulin, GH, IGF-1, and leptin concentrations were determined in a subgroup of multiparous cows (HO $=29$ and crossbred $=31$ ). Serum insulin, GH, and leptin concentrations were determined in triplicate. Insulin concentration was determined using a specific, double-antibody, equilibrium RIA, as described by Kolath et al. (2006). Growth hormone concentration was quantified using a modified RIA from an ovine GH assay (Lalman et al., 2000). Leptin concentration was determined using a competitive, liquid-liquid phase, double-antibody RIA described by Geary et al. (2003). Plasma IGF-1 concentrations were quantified using a commercially available kit (DSL-10-2800 Nonextraction 
IGF-1 ELISA; Diagnostic Systems Laboratories Inc., Webster, Texas). The intra- and interassay coefficients of variation for the assays were $<5 \%$.

\section{Liver Tissue Collection}

In a subgroup of multiparous cows ( $\mathrm{HO}=10$ and crossbred $=10)$, liver biopsies were performed on study $\mathrm{d}-14,7,14$, and 28 . The actual days (mean $\pm \mathrm{SEM}$ ) for each sampling point were $-14.6 \pm 1.2,7.1 \pm 0.2$, $14.3 \pm 0.3$, and $29.5 \pm 0.6$. Hair in the biopsy area, the 11th intercostal space on the right rib cage, was clipped and cleaned aseptically with betadine scrub followed by $70 \%$ ethanol rinse. The area was locally anesthetized ( $5 \mathrm{~mL}$ of $2 \%$ lidocaine hydrochloride solution), and a curved surgical blade (no. 12) was used to make a 2-cm-long incision. A stainless steel trocar was used to insert a cannula through muscle, peritoneum, and liver. Liver tissue samples were obtained as a vacuum was created by drawing the trocar back into the cannula. Liver samples were stored in microcentrifuge tubes and immediately placed in liquid nitrogen. Samples were stored at $-80^{\circ} \mathrm{C}$ until analysis.

\section{Real-Time RT-PCR}

Polymerase chain reaction assays were done according to the protocol previously described (Okamura et al., 2009). Briefly, RNA was extracted from liver tissue using Trizol reagent (Invitrogen, Carlsbad, CA) and transcribed into cDNA by using a high-capacity cDNA reverse transcription kit (Applied Biosystems, Foster City, CA). The cDNA samples were analyzed in triplicate using $2 \times$ SYBR Green PCR Master Mix (Applied Biosystems). Quantitative real-time reverse transcription-PCR was performed using an ABI Prism 7700 machine (Applied Biosystems) and specific primers for insulin receptor B (IRB), total GHR (GHRtot), GHR variant 1A (GHR1A), IGF-1 (IGF-1), ubiquitin, and cyclophilin A. The specific primers sequences were as follows: IRB forward, 5'-TGCACAACGTGGTTTTCATC-3'; IRB reverse, 5'-GTTTCCTCGAAGGCCTAGC-3'; GHRtot forward, 5'-GGTATGGATCTCTGGCAGCTG-3'; GHRtot reverse, 5'-CTCTGACAAGGAAAGCTGGTGTG-3'; GHR1A forward, 5'-CCAGCCTCTGTTTCAGGAGTGT-3'; GHR1A reverse, 5'-TGCCACTGCCAAGGTCAAC-3'; IGF-1 forward, 5'-TTGGTGGATGCTCTCCAGTTC-3'; IGF-1 reverse, 5'-GCACTCATCCACGATTCCTGT-3'; ubiquitin forward, 5'-ATGCAGATCTTTGTGAAGAC-3'; ubiquitin reverse, 5'-CTTCTGGATGTTGTAGTC-3'; cyclophilin A forward, 5'-CACCGTGTTCTTCGACATCG-3' and cyclophilin A reverse, 5'-ACAGCTCAAAAGAGACGCGG-3'. The threshold cycle (Ct) values were used to calculate the relative abundance of mRNA concentrations by using the formula $2^{\Delta \mathrm{Ct}}$, where $\Delta \mathrm{Ct}$, difference in threshold cycle value, was calculated by subtracting the housekeeping gene $\mathrm{Ct}$ value from the sample Ct value.

\section{Statistical Analysis}

Data collected during the study were entered and organized in an Excel spreadsheet (Microsoft Corp., Redmond, WA) and analyzed using SAS (SAS/STAT version 9.2; SAS Institute Inc., Cary, NC).

Data were analyzed by ANOVA for repeated measures using the MIXED procedure of SAS or by ANOVA using the GLM procedure of SAS. Models included breed (HO vs. MO-sired crossbred), parity (multiparous vs. primiparous), season of parturition (first vs. second), and the interactions between breed and parity and between breed and study day. Ante-dependence covariance structure was used for analysis of concentrations of insulin, GH, IGF-1, and leptin and mRNA expressions of IRB, GHRtot, GHR1A, and IGF-1. Unstructured, compound symmetry, and autoregressive (1) covariance structures were tested for analysis of innate immune responses parameters (samples collected weekly from study d -7 to 21) and analysis of cortisol concentration (samples collected weekly from study d -14 to 21 ), and the covariance structure used was chosen based on Akaike's information criterion (AIC). Innate immune responses parameters and cortisol concentration on study d 42 were analyzed by ANOVA using the GLM procedure of SAS. Models included breed (HO vs. crossbred), parity (multiparous vs. primiparous), season of parturition (first vs. second), and the interaction between breed and parity. Statistical significance was defined as $P \leq 0.05$ and statistical tendencies as $0.05<P \leq 0.10$.

\section{RESULTS}

\section{Innate Immune Responses}

Breed was not associated with percentage of LS+ PMNL $(52.5 \pm 2.0 \% ; P=0.41)$ or intensity of LS expression (942.2 \pm 24.1 GMFI; $P=0.68)$ from study d -7 to 21. Similarly, breed was not associated with percentage of LS+ PMNL $(49.7 \pm 3.6 \% ; P=0.39)$ or intensity of LS expression $(1,118.9 \pm 41.1$ GMFI; $P=$ $0.88)$ on study d 42.

Breed was not $(P=0.30)$ associated with percentage of CD18+ PMNL $(75.5 \pm 2.0 \%)$ from study $\mathrm{d}-7$ to 21 . However, breed was $(P=0.04)$ associated with intensity of CD18 expression from study d -7 to 21 (Figure 1), because CD18+ PMNL from crossbred cows 


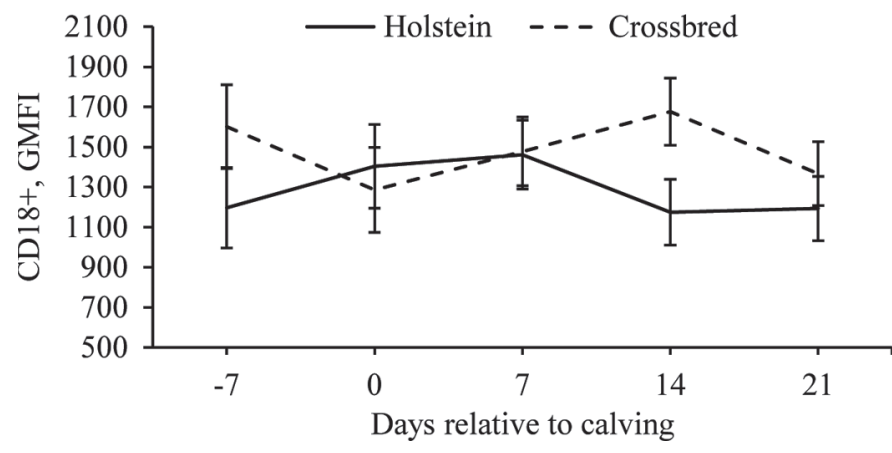

Figure 1. Intensity of CD18 expression in CD18+ PMNL from $7 \mathrm{~d}$ before calving to $21 \mathrm{~d}$ after calving in Holstein and Montbéliarde-sired crossbred cows. Breed: $P=0.04$; study day: $P=0.83$; and breed $\times$ study day: $P=0.45$. GMFI $=$ geometric mean fluorescence intensity.

had greater intensity of CD18 expression than CD18+ PMNL from $\mathrm{HO}$ cows $(1,482.1 \pm 82.3$ vs. $1,286.6 \pm 69.8$ GMFI). On study d 42 , however, breed was not associated with percentage of CD18+ PMNL $(65.8 \pm 4.1 \%$; $P=0.47)$ or intensity of CD18 expression $(1,835.0 \pm$ 150.0 GMFI; $P=0.30)$. Parity tended $(P=0.07)$ to be associated with intensity of CD18 expression from study d -7 to 21 (multiparous $=1,495.0 \pm 47.3$ vs. primiparous $=1,273.0 \pm 113.1$ GMFI). Similarly, parity tended $(P=0.08)$ to be associated with intensity of CD18 expression on study d 42 (multiparous $=1,795.2$ \pm 170.7 vs. primiparous $=1,056.9 \pm 397.3$ GMFI $)$.

We found no $(P=0.15)$ association between breed and percentage of PA+ PMNL from study $\mathrm{d}-7$ to 21 , but the interaction between breed and study day was $(P=0.03)$ associated with percentage of $\mathrm{PA}+$ PMNL (Figure 2). Such an interaction was observed because, among $\mathrm{HO}$ cows, percentage of $\mathrm{PA}+\mathrm{PMNL}$ on study d -7 tended $(P=0.09)$ to be greater compared with percentage of PA+ PMNL on study d 0 , whereas, among crossbred cows, percentage of $\mathrm{PA}+$ PMNL between study $\mathrm{d}-7$ and 0 was not $(P=0.89)$ different (Figure 2). Furthermore, HO cows had $(P \leq$ $0.05)$ greater percentage of PA+ PMNL on study d 7 , 21 , and 42 than crossbred cows, and $\mathrm{HO}$ cows tended to $(P=0.10)$ have greater percentage of $\mathrm{PA}+\mathrm{PMNL}$ on study d 14 than crossbred cows. There was $(P<0.01)$ an association between parity and percentage of $\mathrm{PA}+$ PMNL from study $\mathrm{d}-7$ to 21 (multiparous $=75.5 \pm$ 2.5 vs. primiparous $=52.3 \pm 5.8 \%)$. Parity was not $(P$ $=0.25)$ associated with percentage of PA+ PMNL on study d $42(74.6 \pm 3.4 \%)$. Intensity of PA from study d -7 to 21 did not $(P=0.54)$ differ between PA+ PMNL from $\mathrm{HO}$ and crossbred cows, but the interaction between breed and study day tended to be $(P=0.09)$ associated with PA intensity of PA+ PMNL (Figure $3)$. This interaction occurred because, on study d 0 , $\mathrm{PA}+\mathrm{PMNL}$ from $\mathrm{HO}$ cows tended to have $(P=0.09)$

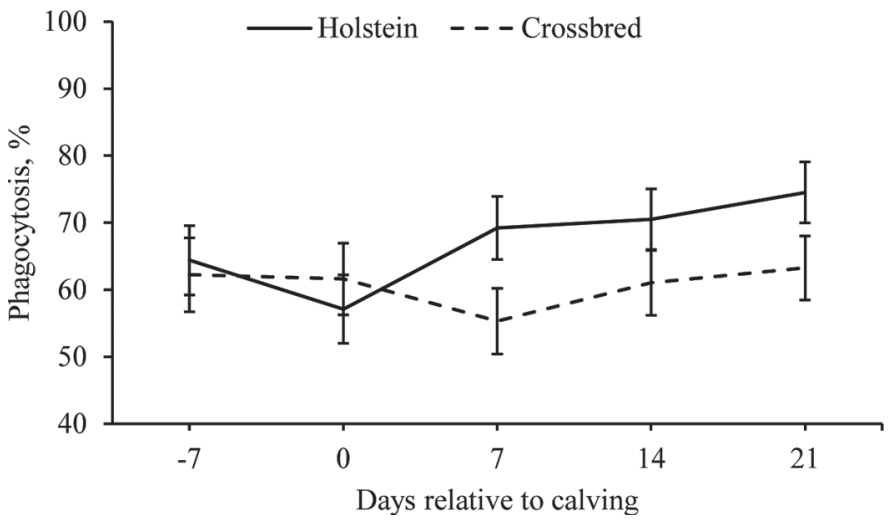

Figure 2. Percentage of phagocytosis positive PMNL from $7 \mathrm{~d}$ before calving to $21 \mathrm{~d}$ after calving in Holstein and Montbéliarde-sired crossbred cows. Breed: $P=0.15$; study day: $P=0.13$; and breed $\times$ study day: $P=0.03$.

reduced PA intensity compared with PA+ PMNL from crossbred cows. Furthermore, PA intensity in PA+ PMNL from HO cows decreased $(P=0.03)$ between study $\mathrm{d}-7$ and 0 , but PA intensity did not $(P=0.20)$ change in in PA+ PMNL from crossbred cows during the same period. On study d 42 , breed was not $(P=$ $0.27)$ associated with intensity of PA of PA+ PMNL. Parity was $(P<0.01)$ associated with intensity of PA from study d -7 to 21 (multiparous $=7,890.2 \pm 504.9$ vs. primiparous $=2,814.3 \pm 1,203.0$ GMFI). Parity, however, was not $(P=0.19)$ associated with intensity of PA on study d $42(10,028.0 \pm 770.0$ GMFI $)$.

Breed was not $(P=0.61)$ associated with percentage of OB+ PMNL from study d -7 to $21(93.8 \pm 0.5 \%)$. Similarly, breed was not $(P=0.81)$ associated with percentage of OB+ PMNL on study d $42(91.4 \pm 1.0 \%)$. Breed was not $(P=0.18)$ associated with intensity of $\mathrm{OB}$ in $\mathrm{OB}+\mathrm{PMNL}$ from study $\mathrm{d}-7$ to $21(22,178.0$

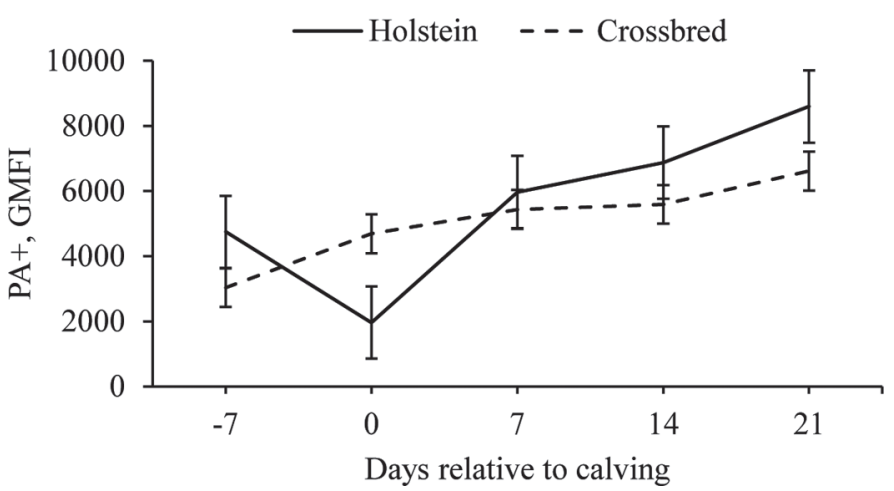

Figure 3. Intensity of phagocytic activity of phagocytosis positive $(\mathrm{PA}+)$ PMNL from $7 \mathrm{~d}$ before calving to $21 \mathrm{~d}$ after calving in Holstein and Montbéliarde-sired crossbred cows. Breed: $P=0.54$; study day: $P<0.01$; and breed $\times$ study day: $P=0.09$. GMFI $=$ geometric mean fluorescence intensity. 
$\pm 1,612.0$ GMFI $)$ or on study d $42(29,781.0 \pm 3,980.0$ GMFI; $P=0.89$ ). Oxidative burst-positive PMNL from multiparous cows had greater $(P<0.01)$ OB intensity from study d -7 to 21 compared with $\mathrm{OB}+\mathrm{PMNL}$ from primiparous cows $(26,085.0 \pm 1,891.0$ vs. $7,883.0$ $\pm 4,608.4$ GMFI). On study d 42 , parity was not $(P=$ $0.20)$ associated with OB intensity $(29,781.0 \pm 3,980.0$ GMFI).

\section{Insulin, GH, IGF-1, Cortisol, and Leptin}

Breed was not $(P=0.69)$ associated with insulin concentration from study d -7 to 56 (Figure $4 \mathrm{~A}$ ). Holstein cows, however, had $(P<0.01)$ greater $\mathrm{GH}$ concentration from study d -7 to 56 than crossbred cows $(7.4 \pm 0.4$ vs. $5.1 \pm 0.4 \mathrm{ng} / \mathrm{mL}$; Figure $4 \mathrm{~B})$. Breed was not associated with IGF-1 $(P=0.82$; Figure $4 \mathrm{C})$ or leptin $(P=0.30$; Figure 4D) concentrations from study $\mathrm{d}-7$ to 56 .

Holstein cows had greater $(P<0.01)$ cortisol concentrations from study d -14 to 21 than crossbred cows $(9.5 \pm 0.8$ vs. $7.1 \pm 0.8 \mathrm{ng} / \mathrm{mL}$; Figure 5$)$. On study d 42, cortisol concentration was $(P<0.01)$ greater for $\mathrm{HO}$ cows compared with crossbred cows $(11.7 \pm 1.6$ vs.
$4.5 \pm 1.5 \mathrm{ng} / \mathrm{mL})$. Primiparous cows had $(P<0.01)$ greater cortisol concentrations from study d -14 to 21 than multiparous cows $(10.9 \pm 1.2$ vs. $5.6 \pm 0.5 \mathrm{ng} /$ $\mathrm{mL})$. On study d 42 , primiparous cows had $(P<0.01)$ greater cortisol concentration than multiparous cows $(11.3 \pm 2.0$ vs. $4.9 \pm 1.0 \mathrm{ng} / \mathrm{mL})$. The interaction between breed and parity was $(P<0.01)$ associated with cortisol concentration on study d 42 because, among crossbred cows, parity was not $(P=0.79)$ associated with cortisol concentration but, among HO cows, primiparous cows had $(P<0.01)$ greater cortisol concentration than multiparous cows $(18.5 \pm 2.8$ vs. $4.8 \pm 1.4$ $\mathrm{ng} / \mathrm{mL})$.

\section{Liver mRNA Expression}

We found no $(P=0.69)$ association between breed and expression of IRB mRNA, but the interaction between breed and study day was $(P=0.02)$ associated with liver expression of IRB mRNA (Figure 6A). Such an interaction was observed because no changes in IRB mRNA expression were observed in crossbred cows, whereas, among $\mathrm{HO}$ cows, IRB mRNA expression tended to be $(P=0.10)$ and was $(P<0.01)$ greater
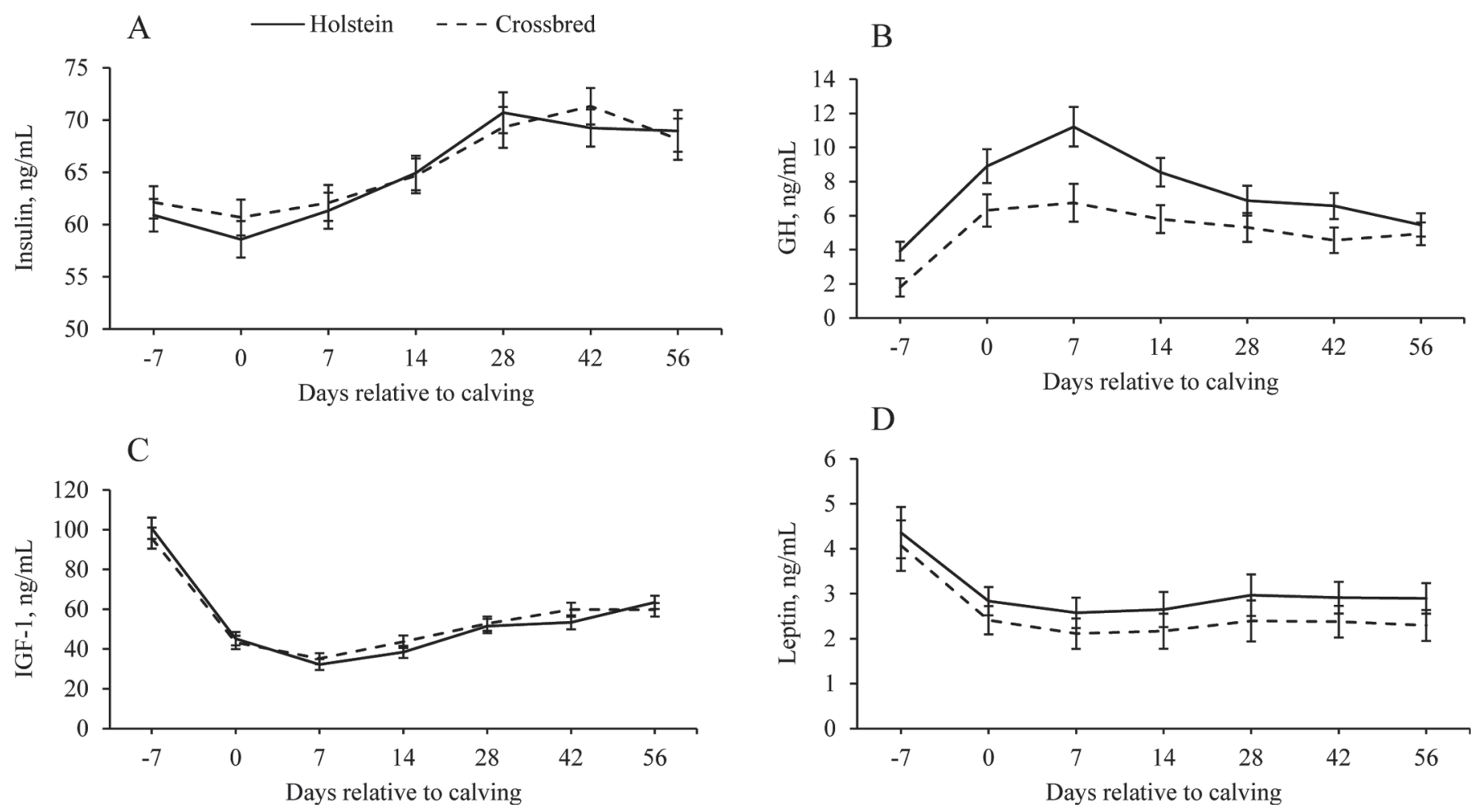

Figure 4. Concentrations of somatotropic axis hormones and leptin from $7 \mathrm{~d}$ before calving to $56 \mathrm{~d}$ after calving in Holstein and Montbéliardesired crossbred cows. (A) Insulin concentration - breed: $P=0.69$; study day: $P<0.01$; and breed $\times$ study day: $P=0.91$; (B) growth hormone $(\mathrm{GH})$ concentration - breed: $P<0.01$; study day: $P<0.01$; and breed $\times$ study day: $P=0.47$; (C) IGF-1 concentration — breed: $P=0.82$; study day: $P<0.01$; and breed $\times$ study day: $P=0.29$; (D) leptin concentration-breed: $P=0.30$; study day: $P<0.01$; and breed $\times$ study day: $P$ $=1.00$. 


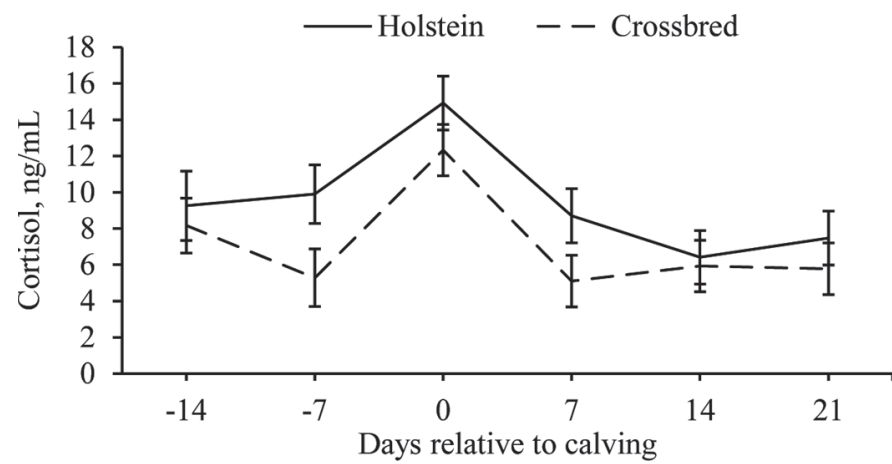

Figure 5. Cortisol concentration of Holstein and Montbéliardesired crossbred cows from $14 \mathrm{~d}$ before calving to $21 \mathrm{~d}$ after calving. Breed: $P<0.01$; day: $P<0.01$; and breed $\times$ study day: $P=0.70$.

compared with IRB mRNA expression on study d 7 and on study $\mathrm{d}-14$ and 28 , respectively, and IRB mRNA expression on study d 14 was $(P \leq 0.04)$ greater compared with IRB mRNA expression on study d -14 and 28. We found no association between breed and expression of GHRtot mRNA $(P=0.81$; Figure $6 \mathrm{~B})$, expression of GHR1A $(P=0.83$; Figure $6 \mathrm{C})$, or expression of IGF-1 mRNA $(P=0.70$; Figure $6 \mathrm{D})$.

\section{DISCUSSION}

Compared with MO-sired crossbred cows, Holstein cows are more likely to be diagnosed with uterine diseases in the postparturient period (63.5 vs. $36.7 \%, P$ $<$ 0.01; Mendonça et al., 2010a) and to die within 35 DIM (Heins et al., 2012). Because PMNL function is fundamental for host defense (Cai et al., 1994) and is associated with occurrence of retained fetal membranes and metritis (Kimura et al., 2002; Hammon et al., 2006), parameters associated with PMNL function were evaluated in the peripartum period of $\mathrm{HO}$ and MOsired crossbred cows. Holstein cows had reduced intensity of expression of CD18, a molecule responsible for the firm adherence of PMNL to the endothelium near areas of inflammation (Burton et al., 1995), compared with crossbred cows, but the intensity of expression of L-selectin was similar between breeds. Furthermore, the interaction between breed and study day was associated with intensity of PA: among HO cows, the intensity of PA on study d 0 was reduced compared with intensity of PA on study $\mathrm{d}-7$ and 7 , whereas, among crossbred cows, the intensity of PA on study d 0 was not different than intensity of PA on study d -7 or 7 . These are important findings because cows
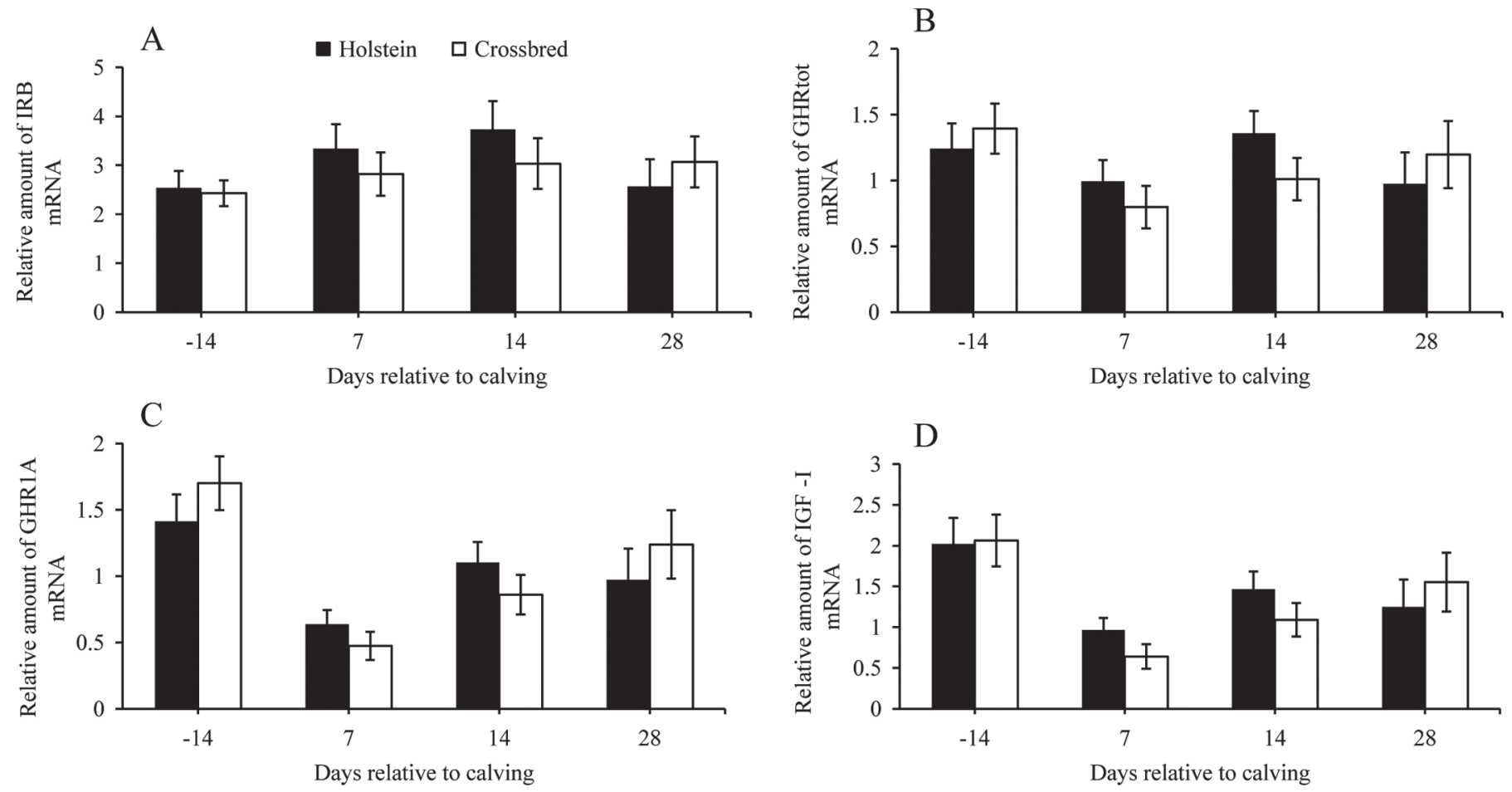

$\mathrm{D}$

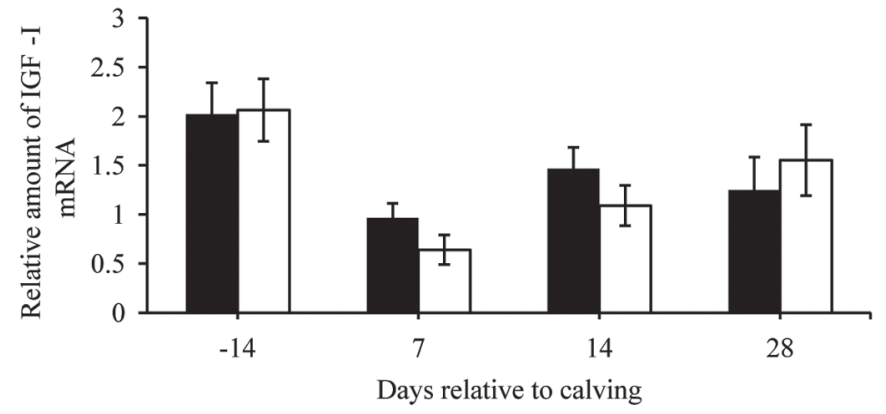

Figure 6. Relative amount of liver mRNA of genes related to the somatotropic axis. (A) Insulin receptor (IR) B mRNA - breed: $P=0.69$; study day: $P=0.02$; and breed $\times$ study day: $P=0.02 ;(\mathrm{B})$ total growth hormone receptor (GHRtot) $\mathrm{mRNA}-$ breed: $P=0.81$; study day: $P=$ 0.08 ; and breed $\times$ study day: $P=0.18$; $(\mathrm{C})$ growth hormone receptor variant $1 \mathrm{~A}$ (GHR1A) mRNA — breed: $P=0.83$; study day: $P<0.01$; and breed $\times$ study day: $P=0.14$; (D) IGF-1 mRNA - breed: $P=0.70$; study day: $P<0.01$; and breed $\times$ study day: $P=0.40$. 
that develop metritis seem to have a significant reduction in activity of PMNL around the time of calving (Hammon et al., 2006) similar to what was observed in $\mathrm{HO}$ cows but not in MO-sired crossbred cows. On the other hand, the increased PA activity of PMNL from HO cows compared with crossbred cows from study d 7 to 21 was likely associated with the tendency for greater incidence of pyrexia in $\mathrm{HO}$ cows compared with crossbred cows ( 50.0 vs. $31.4 \%, P=0.07$; Mendonça et al., 2010a) because pyrexia is triggered by circulating endogenous pyrogens that also stimulate PMNL activity (Dinarello, 2004).

Several endocrine and nutritional factors have been associated with PMNL activity around the time of calving. In the last week of gestation, concentrations of progesterone decrease as concentrations of cortisol, estradiol, prostaglandin $\mathrm{F}_{2 \alpha}$, and prolactin increase (Stevenson, 2007). Cortisol is known to suppress immune response because it downregulates the neutrophil expression of L-selectin and CD18, adhesion molecules involved in the trafficking of neutrophils from the endothelium to the site of inflammation (Burton et al., 1995). Even though we expected that the elevated concentrations of cortisol observed in $\mathrm{HO}$ cows during the periparturient period would be involved with compromised PMNL expression of CD18, when cortisol concentration was included in the model it was not associated with CD18 expression and did not alter the association between breed and expression of CD18. Therefore, it is unlikely that increased cortisol concentrations in HO cows were involved in suppressed PMNL activity and reduced intensity of CD18 expression.

During the periparturient period, dairy cows have reduced feed intake and increased energy expenditure, which result in negative energy balance, elevated adipose tissue mobilization, and increased circulating NEFA concentrations. Holstein cows tended to have reduced DMI in the last $15 \mathrm{~d}$ of gestation compared with crossbred cows (Mendonça et al., 2012), but concentrations of NEFA were not different between breeds $(\mathrm{HO}=0.377 \pm 0.020$ vs. MO-sired crossbred $=0.376$ $\pm 0.020 \mathrm{mmol} / \mathrm{L}, P=0.99$; Mendonça et al., 2010b). Reduced feed intake and increased concentrations of NEFA have been associated with reduced PMNL activity and increased incidence of metritis postpartum (Hammon et al., 2006). Polymorphonuclear leukocytes are primarily dependent on glucose and glycogen as energy sources (Galvão et al., 2010) but the uptake of glucose by PMNL appears to be independent of insulin. Because HO and crossbred cows had similar NEFA and glucose $(\mathrm{HO}=77.23 \pm 0.92 \mathrm{mg} / \mathrm{dL}$ vs. MO-sired crossbred $=76.71 \pm 0.94 \mathrm{mg} / \mathrm{dL} ; P=0.54)$ concentrations throughout the study (Mendonça et al., 2010b), it is not possible to explain the differences in PMNL morphology and function between breeds based on differences in DMI, negative energy balance, or glucose availability.

Holstein and MO-sired crossbred cows demonstrated a decoupling of the somatotropic axis, which was characterized by increased GH concentration and reduced IGF-1 concentrations (discussed below). Several studies have demonstrated an association between IGF-1 and PMNL function and apoptosis in vitro (Inoue et al., 1998; Kooijman et al., 2002). Despite the importance of IGF-1 for the immune system, IGF-1 concentrations were not different between breeds; therefore, it is unlikely that IGF-1 concentration was involved with the differences in intensity of expression of CD18 and intensity of PA between breeds.

As hypothesized, it is likely that heterosis was associated with improved PMNL functionality on the day of calving in MO-sired crossbred cows compared with HO cows. Reduced genetic variability is thought to impair immune responses in populations with elevated inbreeding (O'Brien and Evermann, 1988) and, as mentioned previously, populations of inbred wild birds have compromised cell mediated and innate immune responses (Reid et al., 2003; Townsend et al., 2010). Increased genetic variation resulting from crossbreeding has been associated with greater primary antibody response in Norwegian Red-HO crossbred calves and cows compared with purebred HO calves and cows, respectively (Begley et al., 2009; Cartwright et al., 2011). On the other hand, bovine leukocyte adhesion deficiency, a recessive autosomal genetic disease characterized by mutation in the CD18 gene and impairment of PMNL adhesion (Nagahata, 2004), is an example of how reduced genetic variability and increased inbreeding may compromise innate immune responses.

Uncoupling of the somatotropic axis during the periparturient period is an adaptive characteristic of high-genetic-merit dairy cows to maintain elevated milk yield even during periods of negative energy balance, a characteristic not observed in beef cows (Jiang et al., 2005). As such, during the uncoupling of the somatotropic axis, cows show reduced GHR1A expression in the liver, reduced IGF-1 secretion from the liver, reduced negative feedback of IGF-1 on GH secretion, and, consequently, increased GH and reduced IGF-1 concentrations (Lucy et al., 2009). In the current study, purebred $\mathrm{HO}$ and MO-sired crossbred cows demonstrated uncoupling of the somatotropic axis during the periparturient period because from d 0 to 14 relative to calving GH concentration was greatest and IGF-1 concentrations were lowest as a consequence of reduced expression of mRNA for GHR1A receptor. Holstein cows, however, had greater GH concentrations than MO-sired crossbred cows and similar concentrations of IGF-1 and 
liver expression of GHR1A mRNA compared with MOsired crossbred cows. Lucy et al. (2009) and Grala et al. (2011) demonstrated that genetic strains of the HO breed with elevated genetic merit for milk yield had a more pronounced uncoupling of the somatotropic axis after calving compared with strains with lesser genetic merit for milk yield. In contrast, Okamura et al. (2009) demonstrated that Guernsey cows had similar changes in the somatotropic axis in the periparturient period compared with HO cows. We are unaware of studies evaluating the somatotropic axis of Montbéliarde cows during the periparturient period. The increased concentration of GH in $\mathrm{HO}$ cows compared with MO-sired crossbred but similar IGF-1 concentrations and mRNA expression of GHR1A and IGF-1 in the liver between breeds may suggest that the hypothalamus of purebred HO cows was less sensitive to the negative feedback of IGF-1 compared with MO-sired crossbred, explaining the greater $\mathrm{GH}$ concentration in the former. This may be further evidence that the selection of $\mathrm{HO}$ cows over the years may have favored cows that are more prone to lipolysis during the transition period.

Holstein and crossbred cows had similar insulin concentrations throughout the study, but the interaction between breed and study day was associated with glucose concentration (Mendonça et al., 2010b). This may be an indication that the degree of insulin resistance of HO cows was greater compared with that in crossbred cows. Interestingly, $\mathrm{HO}$ cows had increased expression of liver IRB mRNA on study d 7 and 14 compared with study $d-14$ and 28 ; this pattern of expression of liver IRB mRNA, however, was not observed in crossbred cows. Upregulation of expression of liver IRB mRNA is expected during periods of negative energy balance, particularly during early lactation (Gross et al., 2011). The differences between breeds on liver expression of IRB mRNA may be a consequence of the greater decrease in DMI in the last $15 \mathrm{~d}$ of gestation observed in HO cows (Mendonça et al., 2012). Mid-lactation feedrestricted cows and 21-d-old fetal-growth-restricted lambs had upregulation of insulin receptor mRNA in the liver and muscle, respectively (Muhlhausler et al., 2009; Gross et al., 2011). Even though HO cows had greater expression of IRB mRNA on study $\mathrm{d} 7$ and 14, concentrations of insulin and glucose were similar between breeds, corroborating the hypothesis that the level of insulin resistance in $\mathrm{HO}$ cows may have been greater.

In the current study, $\mathrm{HO}$ cows had greater $\mathrm{GH}$ and cortisol concentrations from $7 \mathrm{~d}$ before calving to $56 \mathrm{~d}$ postpartum compared with MO-sired crossbred cows. Studies that compared hormonal profiles of HO cows of different genetic strains demonstrated that cows with increased genetic merit for milk yield have elevated plasma GH (Lucy et al., 2009; Grala et al., 2011). One possible cause of increased $\mathrm{GH}$ in $\mathrm{HO}$ cows of elevated genetic merit is the observed increased ghrelin concentrations (Roche et al., 2006) compared with HO cows of lesser genetic merit for milk yield. Ghrelin is an endogenous ligand of the GH secretagogue receptor and it stimulates GH secretion and increases appetite (Korbonits and Grossman, 2004), which are believed to be associated with greater milk yield. In the current study, HO cows had greater GH concentrations and greater milk yield than crossbred cows (Mendonça et al., 2010b). Furthermore, administration of ghrelin to cattle stimulates secretion of GH (Itoh et al., 2005) and cortisol (Itoh et al., 2006). Unfortunately, in the current study, ghrelin concentration was not determined.

Even though we expected that HO cows would have reduced leptin concentrations compared with MO-sired cows because the former had reduced BCS throughout the study (Mendonça et al., 2010b), breed was not associated with leptin concentration. Leptin, a hormone produced mainly in adipose tissue, is involved in the regulation of feed intake, energy homeostasis, and reproductive and immune functions (Ingvartsen and Boisclair, 2001). Therefore, it is not possible to explain the differences in innate immune responses in the current study based on leptin concentrations. The lack of difference between breeds in leptin concentration despite the difference in BCS may be explained by the differences in $\mathrm{GH}$ and cortisol concentrations between breeds. Treatment of steers with GH for $3 \mathrm{~d}$ and in vitro treatment of adipose tissue with dexamethasone resulted in upregulation of leptin mRNA expression in adipose tissue (Houseknecht et al., 2000). Therefore, HO cows, despite having reduced BCS compared with crossbred cows, had greater concentrations of GH and cortisol that may have caused upregulation of leptin mRNA expression and may have resulted in similar leptin concentrations between $\mathrm{HO}$ and crossbred cows. This is, however, a simplistic hypothesis because the effects of glucocorticoid and GH on expression of leptin mRNA in adipose tissue in in vivo systems may be interdependent.

\section{CONCLUSIONS}

In the current study, $\mathrm{HO}$ cows tended to have reduced intensity of PA on the day of calving compared with crossbred cows and had reduced expression of CD18 during the periparturient period compared with crossbred cows. Differences in innate immune responses between $\mathrm{HO}$ and crossbred cows could not be explained by differences in concentrations of metabolites or hormones, indicating that heterosis, breed complementarity, or both likely explain differences in innate immune 
responses. The compromised innate immunity of HO cows compared with MO-sired crossbred cows may be the cause of greater incidence of health disorders during the postpartum period in the former breed. Holstein and MO-sired crossbred cows presented uncoupling of the somatotropic axis during the transition period. The greater $\mathrm{GH}$ concentration in $\mathrm{HO}$ cows than MO-sired crossbred cows and similar IGF-1 concentration and liver mRNA expression of GHR1A between breeds, however, indicate that the hypothalamus of HO cows may have been less sensitive to the negative feedback of IGF-1. These differences between breeds are likely a consequence of the different genetic composition and selection of the $\mathrm{HO}$ and MO breeds.

\section{ACKNOWLEDGMENTS}

The authors thank James Linn and the University of Minnesota St. Paul dairy barn staff. The authors also acknowledge the Department of Veterinary Population Medicine (University of Minnesota, St. Paul) for financial support.

\section{REFERENCES}

Begley, N., F. Buckley, E. B. Burnside, L. Schaeffer, K. Pierce, and B. A. Mallard. 2009. Immune responses of Holstein and Norwegian Red $\times$ Holstein calves on Canadian dairy farms. J. Dairy Sci. 92:518-525.

Burton, J. L., M. E. Jr. Kehrli, S. Kapil, and R. L. Horst. 1995. Regulation of L-selectin and CD18 on bovine neutrophils by glucocorticoids: Effects of cortisol and dexamethasone. J. Leukoc. Biol. 57:317-325.

Cai, T. Q., P. G. Weston, L. A. Lund, B. Brodie, D. J. McKenna, and W. C. Wagner. 1994. Association between neutrophil functions and periparturient disorders in cows. Am. J. Vet. Res. 55:934-943.

Cartwright, S. L., N. Begley, L. R. Schaeffer, E. B. Burnside, and B. A. Mallard. 2011. Antibody and cell-mediated immune responses and survival between Holstein and Norwegian Red $\times$ Holstein Canadian calves. J. Dairy Sci. 94:1576-1585.

Dinarello, C. A. 2004. Infection, fever, and exogenous and endogenous pyrogens: Some concepts have changed. J. Endotoxin Res. 10:201-222.

Etherton, T. D., and D. E. Bauman. 1998. Biology of somatotropin in growth and lactation of domestic animals. Physiol. Rev. 78:745761.

Falconer, D. S., and T. F. C. MacKay. 1996. Introduction to Quantitative Genetics. 4th ed. Longman, Essex, UK.

Galvão, K. N., M. J. Flaminio, S. B. Brittin, R. Sper, M. Fraga, L. Caixeta, A. Ricci, C. L. Guard, W. R. Butler, and R. O. Gilbert. 2010. Association between uterine disease and indicators of neutrophil and systemic energy status in lactating Holstein cows. J. Dairy Sci. 93:2926-2937.

Geary, T. W., E. L. McFadin, M. D. MacNeil, E. E. Grings, R. E. Short, R. N. Funston, and D. H. Keisler. 2003. Leptin as a predictor of carcass composition in beef cattle. J. Anim. Sci. 81:1-8.

Grala, T. M., M. C. Lucy, C. V. Phyn, A. J. Sheahan, J. M. Lee, and J. R. Roche. 2011. Somatotropic axis and concentrate supplementation in grazing dairy cows of genetically diverse origin. J. Dairy Sci. 94:303-315.

Gross, J., H. A. van Dorland, F. J. Schwarz, and R. M. Bruckmaier. 2011. Endocrine changes and liver mRNA abundance of somatotropic axis and insulin system constituents during negative energy balance at different stages of lactation in dairy cows. J. Dairy Sci. 94:3484-3494.

Hammon, D. S., I. M. Evjen, T. R. Dhiman, J. P. Goff, and J. L. Walters. 2006. Neutrophil function and energy status in Holstein cows with uterine health disorders. Vet. Immunol. Immunopathol. 113:21-29.

Heins, B. J., L. B. Hansen, and A. De Vries. 2012. Survival, lifetime production, and profitability of Normande $\times$ Holstein, Montbéliarde $\times$ Holstein, and Scandinavian Red $\times$ Holstein crossbreds versus pure Holsteins. J. Dairy Sci. 95:1011-1021.

Houseknecht, K. L., C. P. Portocarrero, S. Ji, R. Lemenager, and M. E. Spurlock. 2000. Growth hormone regulates leptin gene expression in bovine adipose tissue: Correlation with adipose IGF-1 expression. J. Endocrinol. 164:51-57.

Hulbert, L. E., C. J. Cobb, J. A. Carroll, and M. A. Ballou. 2011. Effects of changing milk replacer feedings from twice to once daily on Holstein calf innate immune responses before and after weaning. J. Dairy Sci. 94:2557-2565.

Ingvartsen, K. L., and Y. R. Boisclair. 2001. Leptin and the regulation of food intake, energy homeostasis and immunity with special focus on periparturient ruminants. Domest. Anim. Endocrinol. $21: 215-250$.

Inoue, T., H. Saito, T. Matsuda, K. Fukatsu, I. Han, S. Furukawa, S. Ikeda, and T. Muto. 1998. Growth hormone and insulin-like growth factor I augment bactericidal capacity of human polymorphonuclear neutrophils. Shock 10:278-284.

Itoh, F., T. Komatsu, S. Kushibiki, and K. Hodate. 2006. Effects of ghrelin injection on plasma concentrations of glucose, pancreatic hormones and cortisol in Holstein dairy cattle. Comp. Biochem. Physiol. A Mol. Integr. Physiol. 143:97-102.

Itoh, F., T. Komatsu, M. Yonai, T. Sugino, M. Kojima, K. Kangawa, Y. Hasegawa, Y. Terashima, and K. Hodate. 2005. GH secretory responses to ghrelin and GHRH in growing and lactating dairy cattle. Domest. Anim. Endocrinol. 28:34-45.

Jiang, H., M. C. Lucy, B. A. Crooker, and W. E. Beal. 2005. Expression of growth hormone receptor $1 \mathrm{~A} \mathrm{mRNA}$ is decreased in dairy cows but not in beef cows at parturition. J. Dairy Sci. 88:1370-1377.

Kimura, K., J. P. Goff, M. E. Jr. Kehrli, and T. A. Reinhardt. 2002. Decreased neutrophil function as a cause of retained placenta in dairy cattle. J. Dairy Sci. 85:544-550.

Kolath, W. H., M. S. Kerley, J. W. Golden, and D. H. Keisler. 2006. The relationship between mitochondrial function and residual feed intake in Angus steers. J. Anim. Sci. 84:861-865.

Kooijman, R., A. Coppens, and E. Hooghe-Peters. 2002. IGF-I inhibits spontaneous apoptosis in human granulocytes. Endocrinology 143:1206-1212.

Korbonits, M., and A. B. Grossman. 2004. Ghrelin: Update on a novel hormonal system. Eur. J. Endocrinol. 151:S67-S70.

Lacetera, N., D. Scalia, U. Bernabucci, B. Ronchi, D. Pirazzi, and A. Nardone. 2005. Lymphocyte functions in overconditioned cows around parturition. J. Dairy Sci. 88:2010-2016.

Lalman, D. L., J. E. Williams, B. W. Hess, M. G. Thomas, and D. H. Keisler. 2000. Effect of dietary energy on milk production and metabolic hormones in thin, primiparous beef heifers. J. Anim. Sci. $78: 530-538$.

Lucy, M. C., G. A. Verkerk, B. E. Whyte, K. A. Macdonald, L. Burton, R. T. Cursons, J. R. Roche, and C. W. Holmes. 2009. Somatotropic axis components and nutrient partitioning in genetically diverse dairy cows managed under different feed allowances in a pasture system. J. Dairy Sci. 92:526-539.

Mendonça, L. G. D., C. C. Abade, E. M. da Silva, and R. C. Chebel. 2010a. Comparison of postpartum health, uterine involution, and resumption of ovarian cycles of Holstein and crossbred dairy cows. J. Dairy Sci. 93(E-Suppl. 1):488. (Abstr.)

Mendonça, L. G. D., C. C. Abade, E. M. da Silva, and R. C. Chebel 2010b. Comparison of body condition score, body weight and milk yield and composition of Holstein and crossbred dairy cows. J. Dairy Sci. 93(E-Suppl. 1):673. (Abstr.)

Mendonça, L. G. D., N. B. Litherland, M. C. Lucy, D. H. Keisler, and R. C. Chebel. 2012. Comparison of dry matter intake and somato- 
tropic axis components of Holstein and crossbred dairy cows. J. Dairy Sci. 95(Suppl. 2):81. (Abstr.)

Muhlhausler, B. S., J. A. Duffield, S. E. Ozanne, C. Pilgrim, N. Turner, J. L. Morrison, and I. C. McMillen. 2009. The transition from fetal growth restriction to accelerated postnatal growth: A potential role for insulin signaling in skeletal muscle. J. Physiol. 587:4199-4211.

Nagahata, H. 2004. Bovine leukocyte adhesion deficiency (BLAD): A review. J. Vet. Med. Sci. 66:1475-1482.

O'Brien, S. J., and J. F. Evermann. 1988. Interactive influence of infectious disease and genetic diversity in natural populations. Trends Ecol. Evol. 3:254-259.

Okamura, C. S., J. F. Bader, D. H. Keisler, and M. C. Lucy. 2009. Short communication: Growth hormone receptor expression in two dairy breeds during the periparturient period. J. Dairy Sci. 92:2706-2710

Reid, J. M., P. Arcese, and L. F. Keller. 2003. Inbreeding depresses immune response in song sparrows (Melospiza melodia): Direct and inter-generational effects. Proc. Biol. Sci. 270:2151-2157.

Roche, J. R., A. J. Sheahan, L. M. Chagas, and D. P. Berry. 2006 Short communication: Genetic selection for milk production increases plasma ghrelin in dairy cows. J. Dairy Sci. 89:3471-3475.
Singh, J., R. D. Murray, G. Mshelia, and Z. Woldehiwet. 2008. The immune status of the bovine uterus during the peripartum period. Vet. J. 175:301-309.

Stevenson, J. F. 2007. Clinical reproductive physiology of the cow. Pages 258-269 in Current Therapy in Large Animal Theriogenology. 2nd ed. R. S. Youngquist and W. R. Threlfall, ed. Saunders Elsevier, St. Louis, MO.

Townsend, A. K., A. B. Clark, K. J. McGowan, A. D. Miller, and E. L. Buckles. 2010. Condition, innate immunity and disease mortality of inbred crows. Proc. Biol. Sci. 277:2875-2883.

US Department of Agriculture. 2012. Trend in inbreeding coefficient for Holstein and Red \& White. Accessed Jan. 10, 2013. http://aipl. arsusda.gov/eval/summary/inbrd.cfm.

Walsh, S., F. Buckley, K. Pierce, N. Byrne, J. Patton, and P. Dillon. 2008. Effects of breed and feeding system on milk production, body weight, body condition score, reproductive performance, and postpartum ovarian function. J. Dairy Sci. 91:4401-4413. 